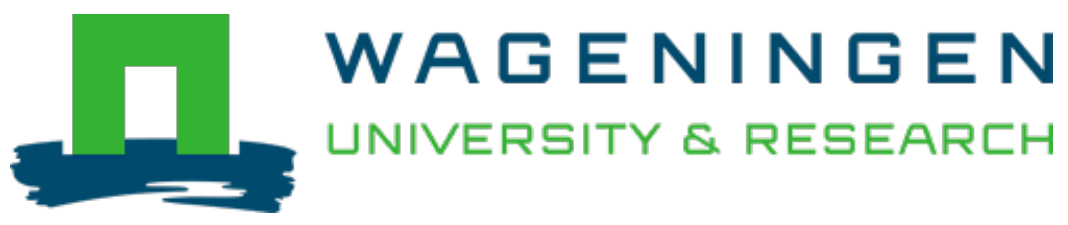

\title{
Recirculation, circular fertilizers and resilience : The potential of growing media systems for circular production
}

\author{
Acta Horticulturae \\ Blok, C.; Verkerke, W.; Boedijn, A.; Streminska, M.; Eveleens, B. \\ https://doi.org/10.17660/ActaHortic.2021.1317.22
}

This publication is made publicly available in the institutional repository of Wageningen University and Research, under the terms of article $25 \mathrm{fa}$ of the Dutch Copyright Act, also known as the Amendment Taverne. This has been done with explicit consent by the author.

Article 25 fa states that the author of a short scientific work funded either wholly or partially by Dutch public funds is entitled to make that work publicly available for no consideration following a reasonable period of time after the work was first published, provided that clear reference is made to the source of the first publication of the work.

This publication is distributed under The Association of Universities in the Netherlands (VSNU) 'Article $25 \mathrm{fa}$ implementation' project. In this project research outputs of researchers employed by Dutch Universities that comply with the legal requirements of Article $25 \mathrm{fa}$ of the Dutch Copyright Act are distributed online and free of cost or other barriers in institutional repositories. Research outputs are distributed six months after their first online publication in the original published version and with proper attribution to the source of the original publication.

You are permitted to download and use the publication for personal purposes. All rights remain with the author(s) and / or copyright owner(s) of this work. Any use of the publication or parts of it other than authorised under article $25 \mathrm{fa}$ of the Dutch Copyright act is prohibited. Wageningen University \& Research and the author(s) of this publication shall not be held responsible or liable for any damages resulting from your (re)use of this publication.

For questions regarding the public availability of this publication please contact openscience.library@wur.nl 


\title{
Recirculation, circular fertilizers and resilience: the potential of growing media systems for circular production
}

\author{
C. Blok, W. Verkerke, A. Boedijn, M. Streminska and B. Eveleens \\ Wageningen University \& Research, Greenhouse Horticulture, Wageningen, The Netherlands.
}

\begin{abstract}
Current thinking about circularity and sustainability is used to identify i) recirculation of drainage water, ii) circular fertilisers, and iii) resilience control as growing media related areas with a wider societal meaning. The objectives are to find to which extent circularity can be realized and how growing media and compost research can serve transition to a more circular horticulture. Recirculation of drainage water increases water use efficiency by $50 \%$, nutrient use efficiency by $60 \%$ and eliminates the emission of water borne chemical agents. The challenge remains as still $\mathbf{9 0 \%}$ of the global area of growing media systems does not yet use available techniques to realize full recirculation. The global use of more circular fertilisers, including plant, animal and human wastes, can stop depletion of natural reserves and diffuse emission of nutrients. It is argued that the combination of irrigation techniques and the use of growing media offer horticulture both opportunity and reasons to lead in the production of circular fertilisers, being either soluble or slow release. Resilient growing media facilitate cultivation without chemical agents, without disinfection before reuse and without continuous disinfection of recirculating water. We identify methodological improvements still needed to safely progress on this road. The importance of growing media based cultivation is put in perspective of the global production of food and ornamentals.
\end{abstract}

Keywords: nutrient reuse, organic fertilisers, plant improvers, plant protection, resource use efficiency

\section{INTRODUCTION}

At present the economy is embracing the concepts of circularity and sustainability (OECD-FAO, 2021; OECD, 2021). Apart from reacting to the societal demands originating from circularity and sustainability, growing media research can help to focus on applications which hold the largest potential benefits for society and horticultural industry alike (Zhou et al., 2021). At the beginning of this article we will explore the field and select the most promising applications. Selected applications will then be discussed in more depth. Finally, in a general discussion, the importance of growing media based, and circular cultivation will be discussed in perspective of the global production of food and ornamentals.

\section{Circularity}

For circular agriculture one definition reads: “a) Production of agricultural commodities using a minimal amount of external inputs, b) Closing nutrient loops and reducing negative discharges to the environment, and c) Valorising agri-food wastes" (Ward, 2017). Circularity in the realm of horticulture in the Netherlands came into focus with introduction of the new research agenda of the Ministry of Agriculture, Nature and Food Quality (LNV, 2019). Circular agriculture being described as "a paradigm shift from growth in production volumes and cost price reductions towards optimisation in resource use and food production in harmony with nature". This is in line with global trends (Raworth, 2017; Attenborough, 2020; IPBES, 2019). Although much attention in the ministry document is focused on animal husbandry and openfield agriculture, the ministry also ordered a pilot study to identify and rank priorities for the horticultural industry. In reaction an important stakeholder group within the horticultural 
supply industry ordered additional research to identify possibilities to improve their services (Figure 1). In these studies the main areas of interest were identified as: 1) reducing the use of fossil energy sources; 2) reducing the emission of fossil carbon dioxide; 3) increasing water use efficiency and decreasing waterborne emissions; 4) decreasing the use of non-circular fertilisers; 5) decreasing the use of non-circular growing media; 6) decreasing the use of oil based persistent materials e.g. plastics.

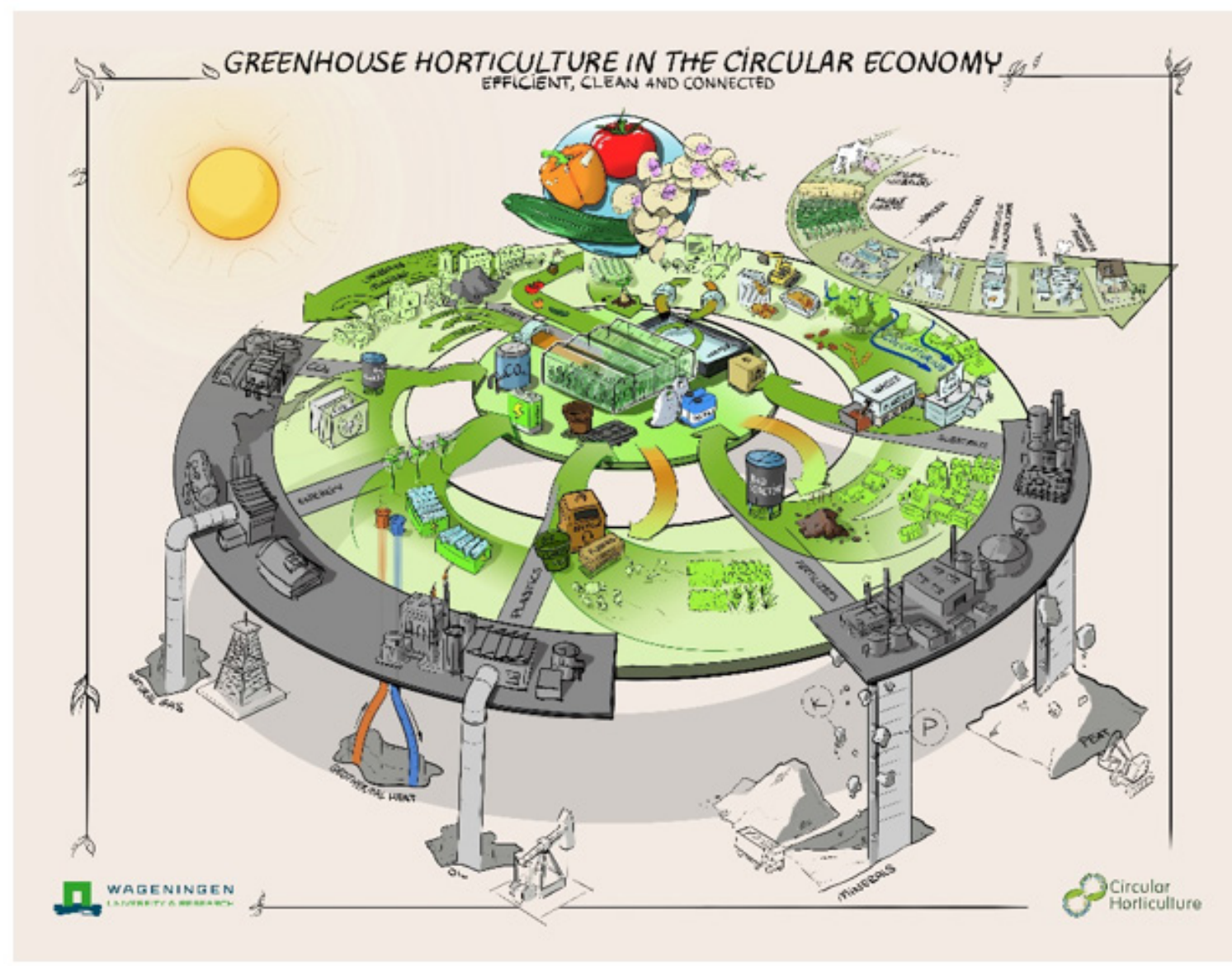

Figure 1. Artist impression of circular horticulture dealing with various transitions. From left to right on the gray outer circle: Carbon dioxide from fossil energy sources; energy from fossil energy sources; plastics from fossil energy sources; fertilisers from noncircular sources and by using fossil energy; growing media using fossil carbon sources. Solutions are in the inner circle. The second circle, right hand top, shows how horticulture can use waste materials from other societal segments to create value (Verkerke and Boedijn, 2020).

The reduction in the use of fossil energy for horticultural production is already a focus of research in the Netherlands for decades (Van der Velden et al., 2018; Van der Velden and Smit, 2019, 2020). For tomato, this resulted in a reduction in the use of fossil fuel from 50 to $12 \mathrm{~m}^{3} \mathrm{~m}^{-2}$, expressed as gas equivalents in which $1 \mathrm{~m}^{3}$ gas equals $32 \mathrm{MJ}$. The reduction leans partly on the increased input of green electricity. As this article focuses on a relation with growing media and compost, circular energy will not be further discussed.

The reduction in the use of fossil carbon dioxide has, at least in the Netherlands, been pursued by using carbon dioxide from industrial sources (Van der Velden and Smit, 2019) of which $50 \%$ is circular carbon dioxide, and by reducing the amounts dosed from 140 to $20 \mathrm{~kg}$ $\mathrm{m}^{-2}$ year-1 by tuning application to the demand (De Gelder et al., 2019). An indirect relationship with growing media lies in the use of bioreactors and compost facilities to co- 
produce carbon dioxide. Said bioreactors also produce circular nutrients especially for horticultural purposes. As this article focuses on a relation with growing media and compost, circular carbon dioxide will not be further discussed.

The obligatory application of recirculation of drainage water in Dutch horticulture reduced emissions from at least $50 \%$ of the supplied volume in 1980 to less than $10 \%$ in 2020 (Beerling et al., 2017). The need to increase water use efficiency has also been subject of world-wide studies for over 20 years (OECD-FAO, 2014; Stanghellini, 2014; Stanghellini et al., 2019). The single most effective way to increase water use efficiency was shown to be the collection and re-use of the drainage water. As a total reuse of drainage water automatically recirculates all water borne fertilizers and crop protection agents, this strategy conveniently takes care of the emission of nutrients and crop protection agents (Gruda, 2020).

The use of nutrients in glasshouse horticulture on a national scale is 100.000 t year-1 $^{-1}$ on

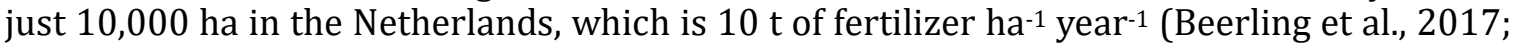
Van Os et al., 2019). Although the use of circular fertilisers is increasing, we estimate less than $10 \%$ of the total fertiliser use in Dutch horticulture is circular. We define circular fertilisers as fertilisers from renewable sources, not resulting in substantial accumulation in the environment. We describe the opposite of circular fertilisers as "noncircular fertilisers" because alternative terms as linear, chemical, synthetic, and non-renewable all have unintended exceptions. As just one example, the production of nitrogen fertilisers from air with solar energy is renewable but not circular. The conversion from non-circular to circular fertilizers in Dutch horticulture is realized by large base dressings and repeated maintenance dressings of solid organic fertiliser (Gonani et al., 2011; Viaene et al., 2017), by preparing solid circular fertilizers with slow release properties (Van Staalduinen and Verhagen, 2020) and by preparing a liquid organic fertilizer mix (Blok et al., 2017b, c). The development of liquid circular fertiliser will facilitate the continued use of drip irrigation systems. Drip irrigation systems are deemed essential to realize yield advantages related to high frequency supply of water and nutrients (Xu et al., 2004; Silber et al., 2005). Globally the conversion from noncircular to a more circular nutrient supply is perceived as a huge challenge for agriculture (Foley et al., 2005; Dogliotti et al., 2014). To date the emphasis lays on the conversion from non-circular to circular fertilizers in arable cropping rather than in horticulture, but we will argue there are reasons to deem the development of circular fertilisers for growing media and composts especially relevant.

The decrease in the use of fossil growing media at present focuses on finding peat alternatives (Gruda, 2020). Arguments are peat is a finite, natural resource and peat use results in carbon dioxide emission upon oxidation in air. In the Netherlands the percentage of peat used in professional horticultural media decreased from $75 \%$ of the total in 1990 to $65 \%$ in 2017 (Blok and Verhagen, 2009; Blok et al., 2021). The decrease of percentage of peat in consumer growing media from about $70 \%$ to about $50 \%$ was even larger. Even so, the import of peat in absolute quantity hardly decreased. As peat is by far the most versatile and qualitatively most convenient growing media, finding alternatives still poses a major challenge, of which the industry is well aware (Schmilewski, 2009; Carlile and Waller, 2013; Barrett et al., 2016; Vandecasteele et al., 2021). Large scale alternatives at present are coir products, wood fiber products, bark, perlite and to a lesser extent woody compost. Although this article focuses on a relation with growing media and compost, finding peat alternatives will not be further discussed. The reason is that "peat free" will not highlight the unique potential of growing media systems.

The reduction in the use of synthetic supporting materials (clips, foils, wires, containers), serves two environmental purposes: 1) avoiding the use of fossil sources for production reduces the release of carbon dioxide and its role in climate change; 2 ) the physical and microbial degradation takes a very long time. The consequence of this poor microbial degradability is a dispersion of plastics in the environment, known as, among others, "plastic soup" for larger particles and "micro plastics", when broken down in very small particles. Both problems interfere negatively with fauna on earth. The solution is to produce alternative materials with similar essential properties in use but with a biobased source material (Eveleens and Blok, 2020), and with a reliable biological degradability (EN-13432, 2017; EN- 
17033, 2018). Scientists studying horticultural growing media and composts may adapt existing methods to measure biological degradability of such novel materials. Alternatives for oil based poorly degradable pot plant containers, crop wires, crop clips and packaging foil are on the market, but are by no means leading products yet in the Netherlands. As this article focuses on a more direct relation with growing media and compost, this issue will not be further discussed.

\section{Sustainability and resilience}

Sustainable cultivation defined as "cultivation capable of maintaining productivity indefinitely" (OECD, 2021) overlaps considerably with "circular agriculture". The terms "sustainable" and "circular" however, do not include resilience. Something which is sustainable does not have to be resilient even though resilience is, in many cases, an important characteristic of a sustainable system. Resilience contributes to sustainable cultivation when the level of resilience is sufficient to maintain crop health over the cultivation cycle via a growing medium which is suppressive to plant pests and diseases. This definition puts the focus on both, biocontrol agents for disease suppression and biostimulants for improved plant health by a substance or a microorganism (Du Jardin, 2015). The field of this type of growing media mediated resilience is vast and as yet still not explored to a level of understanding which allows for large scale applications (Raviv, 2009; Grunert et al., 2016a; Debode et al., 2018; Grunert et al., 2019). However, the example of the success of above ground control of pests with integrated pest management (IPM) motivates research to broaden this concept to include above and below ground microorganisms (Alabouvette and Steinberg, 2006; Termorshuizen et al., 2006; Khalil et al., 2011; Vestberg et al., 2011). As this research field is vast, relations are complex and studies are conducted by researchers with widely differing backgrounds, there is still room for overviews with a focus on application in commercial growing media based horticulture (Lugtenberg, 2015; Joos et al., 2020).

\section{Selection and objective}

We conclude this introduction by selecting from the topics regarding circularity and sustainability just 3 subjects; recirculation of water and nutrients, the use of circular fertilisers and the management of microbiology in growing media. Our reason to select these topics is we think these topics can best put horticulture in the center of innovating world food production. Arguments for this choice, however arbitrarily, are: 1) growing media based systems have a unique possibility for total recirculation i.e. zero discharge, of water, fertilisers and, when these are applied, water borne plant protection agents; 2) the development of circular fertilisers puts pressure on the use of drip irrigation. Drip irrigation is such a valuable tool for horticulture, it is worthwhile to invest in adapting the circular fertilisers and such adaptions are relevant for outdoor drip irrigation applications too; 3) the management and study of microbial resilience in growing media can surpass that dedicated to arable soils as the control over climate and abiotic factors in most horticultural systems is easier. Other aspects of circularity as energy, carbon dioxide, growing media choice and substitution of plastics are left out as these aspects do not in our opinion offer a unique possibility for growing media research and development to develop solutions of global relevance.

The objective of this article is to better define to which extent circularity in growing media can be reached in the areas of emission, circular fertiliser and resilience control and how the study of growing media and composts can serve the conversion of current horticulture to a more circular horticulture. To do the above, the importance of growing media based cultivation will be put in perspective of the much larger global production of food and ornamentals.

\section{STATE OF THE ART}

\section{The recirculation of drainage water}

The worldwide irrigated land area is $3.4 \mathrm{Mkm}^{2}$ (FAO, 2017) or $19 \%$ of the total cropland area or $18 \mathrm{Mkm}^{2}$ (FAO, 2020). The production on irrigated land is $45 \%$ of the world production 
of arable crops (FAO, 2017) which means average production per unit area on irrigated land is almost 3.5 times the production on non-irrigated land. To supply enough food for the anticipated $10 \mathrm{~B}$ people in 2050 (UN, 2021), the area of irrigated land is supposed to further increase (OECD-FAO, 2021). However, irrigation is in many cases inherently unsustainable and the amount of water available is becoming limiting. The element load of most water is high enough to lead to accumulation of such elements in the topsoil. To prevent yield reduction because of too high levels of individual elements, over-irrigation, with an average $50 \%$ of water, is common (Stanghellini, 2014). Inevitably the result is emission of fertilisers, notably $\mathrm{N}$ and $\mathrm{P}$, as well as crop protection agents. Nutrient emission thus also applies for irrigated organic production systems. Irrigated agriculture is already using a hotly debated $70 \%$ of the world's fresh water sources making a further substantial increase of the irrigated area unlikely (UNESCO, 2019). Options to increase irrigation efficiency by pre-treating irrigation water with e.g. reverse osmosis (RO) techniques or reusing municipal or industrial wastewater seem to offer some room. Such adaptations however come with a price tag of 0.53 Euro $\mathrm{m}^{-3}$. Our argument here is that such higher prices and technological requirements favor horticultural applications.

In growing media based systems, the full recirculation of drainage water is technically possible and, at least in the Netherlands, feasible. With or without recirculation, drainage is a prerequisite. Individual differences between plants/crops, and between supply via e.g. drippers, create differences which are evened out with about $15 \%$ drainage water. In practise the required $15 \%$ translates into $30 \%$ drainage water for crops with a very uniform plant development such as tomato and $50 \%$ for less homogeneous crops such as roses. Furthermore the nutrient level expressed as electrical conductivity (EC) around roots and in drainage water needs to be $25-50 \%$ higher than the level in the plant supply (Blok et al., 2017a). The consequence is that $30 \%$ drainage of water means $50-60 \%$ of nutrient loss if drainage water is not recirculated. Based on a supply of $10 \mathrm{mmol} \mathrm{L}^{-1} \mathrm{NO}_{3}$ and $1 \mathrm{mmol} \mathrm{L}^{-1} \mathrm{PO}_{4}$, this results in $\mathrm{N}$ and $\mathrm{P}$ emissions of about $3 \mathrm{t}$ nitrate $\mathrm{ha}^{-1}$ year $^{-1}$ and $0.5 \mathrm{t}$ of phosphate $\mathrm{ha}^{-1} \mathrm{year}^{-1}$ if the drainage water is not recirculated.

Horticultural systems with growing media and recirculation of drainage solution can be effectively realized only if there is a) high quality water and b) an ample supply. High quality meaning an $\mathrm{EC}<0.5 \mathrm{dS} \mathrm{m}^{-1}$, no problems with $\mathrm{pH}<5.0$ or $>6.5$ and all element levels below the plant uptake levels, i.e., below levels resulting in accumulation, which is especially relevant for sodium levels (Sonneveld and Voogt, 2009). If the available water does not meet these requirements, pre-treating the water with various techniques is necessary. Standard, and recently improved AI (Artificial Intelligence) controlled, RO systems meet such demands for most places in the world (HortiDaily, 2020). Areas with high levels of fluoride (e.g. areas in Kenya, Colombia) or boron (e.g. areas in the Middle east) require additional pre-treatments. An ample supply means ideally the supply of rain, well, and/or RO water is enough to cover the daily crop demand over a whole cultivation cycle. In practise this usually includes a water storage such as a basin or silo, to cover yearly crop demand with a reliability for at least 9 out of 10 years for that site. Models to calculate storage capacity for any crop/climate/water price combination exist (Van Os et al., 2009). An important advantage here may be that crop demand for water per unit product in growing media based systems can be up to ten times lower than in irrigated open field situations. This is caused by a combination of the higher yield and the lower evaporation and transpiration in a greenhouse environment (Zhou et al., 2021).

\section{The use of more circular fertilisers}

The reason to reintroduce more circular fertilisers is based on both depletion of scarce resources and decrease in biodiversity. The depletion of scarce resources is relevant for phosphorous, potassium and molybdenum (Sonneveld and Voogt, 2009; Withers et al., 2014). Furthermore, although most mineral fertilisers are excavated from geological deposits, nitrate and ammonia are produced from nitrogen in the air by using $25 \mathrm{GJ} \mathrm{t}^{-1}$ ammonia (IFA, 2014). The amount is so huge, about $1.2 \%$ of the world's energy budget is currently used to produce nitrogen fertilisers (IFA, 2014). The second argument, the decrease in biodiversity, is the 
result of the eventually diffuse emission of any non-circular fertiliser element. Any element supplied to a plant will eventually be released into the environment, be it by drainage emission, plant waste, animal waste or human waste after consumption. Because non-circular fertilisers are freshly dug or produced each year, the amounts of diffuse emissions are cumulative. Accumulation of non-destructible elements would, after another 1000 years of the present-day fertiliser application, lead to over-fertilisation of every biotope. We can already see the results in the rapid decline of biodiversity. Numbers of species of microorganisms in non-circularly fertilised arable land are 10-1000 times lower than in circularly fertilised lands. Insects species in Western Europe have decreased by $70 \%$ and this is attributed in a large degree to fertiliser use (Erisman et al., 2016; WallisDeVries and van Swaay, 2017).

Circular fertilisers solve the problems stated above by a clear shift in sources. The sources of the future are by nature the opposite of the emission routes mentioned: they allow the recirculation of drainage water, re-use of plant waste, animal waste and human waste after consumption. Circular fertilisers do need specific adaptations when used in growing media cultivation. In growing media with recirculation, the required amount of fertilizers prohibits the application of all nutrients already as base dressing before the plants are introduced. The amount required (10 $\mathrm{t} \mathrm{ha}^{-1}$ year-1) $^{-1}$ is just too high to put in a volume of $10-40 \mathrm{~L} \mathrm{~m}^{-2}$. Applying all fertilizers at once would result in $1 \mathrm{~kg}^{4} \mathrm{~L} \mathrm{~L}^{-1}$ for example which would give an EC of about $25 \mathrm{dS} \mathrm{m}^{-1}$; ample to kill the plant. This means circular fertilizers need to be offered as base dressing of slow release fertiliser and/or as a frequently applied maintenance dressing. The only practical way to frequently apply fertilizers to all containers or slabs in a nursery is to add the fertilizers to water and to fertigate.

Slow release fertilizers with polymer coatings release microplastics from the coating which is hardly circular. This means a lot of effort should be and actually is put into production of biobased and biodegradable coatings. Furthermore, the volume per unit element of nonchemical fertiliser sources is often much larger than for chemical fertilisers. Circular slow release fertilisers are thus often compressed to reduce volume and at the same time to slow down the release of elements into a growing medium. As most circular growing fertilisers are hygroscopic, expand when moistened, and then release a lot of ions in solution, there is still ample room for technological advances in creating circular slow release fertilisers by any combination of compressing, coating, impregnating or binding.

Circular water-soluble fertilisers are another option already in the market. Animal or plant wastes are processed into a concentrated multi-element liquid system. An example is Viscotec blue, a plant-based mix with potassium amino acids, offered as a water-soluble powder (DCM, Grobbendonk, Belgium). In experiments with one particular set of circular liquid fertilisers the $\mathrm{pH}$ dropped quite fast from 5.5 to below 4.0 as bacteria take in large amount of ammonium (Blok et al., 2017c). The conversion from ammonium to nitrite is the second bacterial conversion step, and in growing media systems it takes days to weeks before there are enough bacteria to provide this service. A typical increase in nitrite level is then followed by an equally typical increase in nitrate coupled with a drop in nitrite as the conversion nitrite-nitrate is many times faster than the supply by the ammonium-nitrite conversion. At the same time carbon in the fertiliser is converted into carbon dioxide. The production of carbon dioxide in the experiment resulted in bicarbonate levels as high as 15 mmol L-1 and decreased the level of available oxygen in the growing medium. In the experiment described, this resulted in lower growth in peat slabs with organic nutrient supply but not in peat slabs with a chemical nutrient supply. The situation was remedied by allowing slabs to become fractionally drier. Practical and theoretical evidence of small changes in water content influencing the rate of oxygen supply enough to influence production in practical circumstances exists (Verhagen, 2013; Blok et al., 2017a, c). Another way to rework organic waste into a solution fit to distribute with drip irrigation is to use a bioreactor to pre-treat a solution with a high level of organic nitrogen and thus convert a large part of organic nitrogen into nitrate before sending the solution to the crop (Blok et al., 2017b). The use of bioreactors to prepare a nutrient solution at a nursery is now commercially exploited (van der Knaap Group, Kwintsheul, The Netherlands; Biota, Bleiswijk, The Netherlands). 


\section{The co-production of carbon dioxide.}

The bioreactor described above produces a steady flow of nutrient solution at an EC of $4.5 \mathrm{mS} \mathrm{m}^{-1}$, which is the reason it operates on site at the nursery rather than transport such a diluted fertiliser solution. Using bioreactors offers the additional advantage of carbon dioxide, which is inevitably coproduced, and which may be distributed in the greenhouse as fertilisation for the crop. Calculations indicate $20-80 \%$ of the crops needs for carbon dioxide may be covered by such systems although experimental proof is still lacking.

\section{The control over resilience in time}

All plant production systems (arable crops, trees, horticulture and others) are under pressure to reduce or even abandon the use of chemical crop protection agents (Leymonie and Perata, 2013). With the successes in insect control in horticulture, with integrated pest management (IPM) in mind, similar successes are sought after in growing media. The focus is on the control of plant pathogenic organisms such as bacteria, fungi and nematodes (Antoniou et al., 2017; Debode et al., 2018; Tian et al., 2019; Gerrewey et al., 2020). Various ideas on how to bring this about exist.

\section{Hopeful indications.}

Postma (2004) describes how suppressiveness of diseases tends to build up over the years. This observation is supported by the well documented increase of resilience in soil against Take All in wheat (Raaijmakers in Lugtenberg, 2015). This notion has not found much follow up, possibly because common practise in rooting media based cultivation is to change the rooting medium every 1-2 years (as mentioned by Postma 2004). It does however mean it is possible to improve resilience by growing in the same rooting material for over 4 years. At the same time, it is possible to infect a new virtually sterile rooting medium with the population from an old similar rooting medium, without losing the added resilience against Pythium (Postma, 2004). The suppressiveness found is the result of the evolution of activity of whole microbiota.

\section{Single added microorganism.}

Experiments in petri dish are a first step during screening of multiple microorganisms against a specific plant pathogens (Alabouvette and Steinberg, 2006). Experiments in greenhouse and field should follow. Almost all biocontrol agents and microbial biostimulants on the present-day market are based on single microorganism (or even a specific strain). Problem is that single strains might not always work in different environments. Some require the presence of helper strains, which might not be present in every soil/substrate. Many single organisms were tested (Weller et al., 2002; Hultberg et al., 2008).

\section{Multiple added microorganisms.}

This approach was put into practical use by various companies. To increase the chance of success, mixes of several species of disease suppressing microorganisms were put together in a formulation. The reason to do so were the often-disappointing results with the addition of single microorganisms to a growing medium. This approach works, if the different used microorganisms interaction is well studied. Using mixes of random isolates of different species has little chance of success. There are enough potentially disease suppressing microorganisms which can colonize new environments, but even then, their presence does not always equal activity against the targeted disease.

\section{Carriers.}

The next step was to try to find a second growing medium specifically suitable for the added microbials and then first establish the microbials to be added on the second growing medium after which it could be mixed with the first growing medium. In this way the second growing medium acted as a carrier. Soil restoration inoculation shows similarities to using carrier material in substrate growing (Muter et al., 2017). The difference is, in soil restoration use is made of natural occurring communities from other soils, while the carriers are pre- 
treated with beneficial microbials. Successful specific applications of the carrier approach are well documented (Glodowska, 2014; Debode et al., 2018). Drawbacks of the carrier approach may be: a) it is often supposed rather than proven a specific carrier material is a proper host environment for the microbials added; $b$ ) it is often supposed rather than proven the added microbial(s) on the carrier will improve resilience in a growing medium when mixed into that growing medium. Some lessons from soil restoration research (Wubs et al., 2018):

a) Low nutrient fertile soils react more positive to inoculation;

b) Mixing various inoculants results in more pronounced growth reactions of plants i.e. mixing inoculants adds to the effect of the mixing constituents;

c) The mixing ratio matters: $25 / 75 \mathrm{v} / \mathrm{v}$ is not $75 / 25 \mathrm{v} / \mathrm{v}$.

\section{Functional groups fed with specific organic feeds.}

At present there is a lot of attention on feeding the naturally present microbials of a growing medium, rather than introducing new species into a specific environment of soil/growing substrate. This can be achieved by adding specific, organic amendments, which is the nutrient source for the specific groups of beneficial microbes (Grunert et al., 2016b). This is known as stimulating a functional group. Functional groups of microbes are comprised of different species, which can take part in a specific metabolic process, such as for example nitrification of degradation of chitin. Examples are the addition of spent mushroom compost and chitin (Cretoiu et al., 2013; Postma and Schilder, 2015; De Tender et al., 2019). Up to now most organic amendments are administered only once during the cultivation cycle due to their insolubility in water and sometimes even on a very restricted spot, i.e. between the propagation cube and the cultivation slab.

\section{The plant.}

Because specific exudates influence the functional groups of microbials growing in the rhizosphere (Grunert et al., 2019), it is no surprise that plant species with different exudation create soils with different microbiological communities and different susceptibility to (different) diseases (Ma et al., 2017). Ma et al. (2017) showed how soil from plots with grasses positively influence the growth and resilience of plants grown on this soil afterwards i.e. the plant shapes the microbiome which in turn influences the next plant.

\section{Methods to follow and characterize resilience.}

It is still quite difficult to characterize resilience of a growing medium with or without added microorganisms. Present day field methods to estimate the activity of a specific microorganism include quantitative polymer chain reaction (qPCR) and the phospholipid fatty acid method (PLFA). Characterizing potential resilience is heavily depending on the correct application and interpretation of the fast evolving gamma of methods (Joos et al., 2020; Reinhardt and Sharma, 2019). As an example; success of applying a certain feed to stimulate a functional group can be measured by a) the rate of disappearance of the substance applied; b) the rate of appearance of a product out of the substance applied; c) the quantity of enzyme a functional group uses to convert the feed; d) the quantity of RNA used to code for the required enzyme; e) the quantity of DNA coding for the RNA which codes the required enzyme (Figure 2). It is not always possible to use each of these methods as e.g. substance applied and/or product are not unique; enzymes are not unique or unknown etc. Also, the absolute quantities of enzymes, RNA or DNA can be misleading. Some enzymes are much more productive than others, some RNA to enzyme conversions are much more effective and some DNA may be present but inactive.

\section{DISCUSSION}

\section{Growing media proper}

The topic of new growing media constituents and peat alternatives was not selected as objective in the introduction, because growing media choice was assumed not to show a unique potential inherent in the use of soilless culture systems (SCS). However, several peat 
alternatives in themselves harbour unique properties which could make growing media cultivation relevant for society. A first example is the re-use of local organic waste materials as growing medium (Vandecasteele et al., 2018; Vandecasteele et al., 2020). Some examples are composts, park waste-based wood fibers, and used growing media. A second example is the use of biochar, which, after use in soilless cultivation, can be added to arable soils and by increasing the soil organic matter content results in a negative carbon dioxide emission i.e. as a regenerative product (Fryda et al., 2019). A third example is the use of water as a growing medium, avoiding the use of growing media all together (Blok et al., 2017a). Another reason to discuss the circularity of growing media is that spent growing media are not circularly reused. Most organic growing media end up as soil improver or low-grade potting soil. And although it can be argued this contributes to wider and more complex circularity it may also be argued this is an imperfect solution. Obviously inorganic growing media such as perlite or stone wool are at present even more linear products. The remarks above are given to show the choice of objectives was not meant to avoid critical thinking about the circularity of growing media proper.
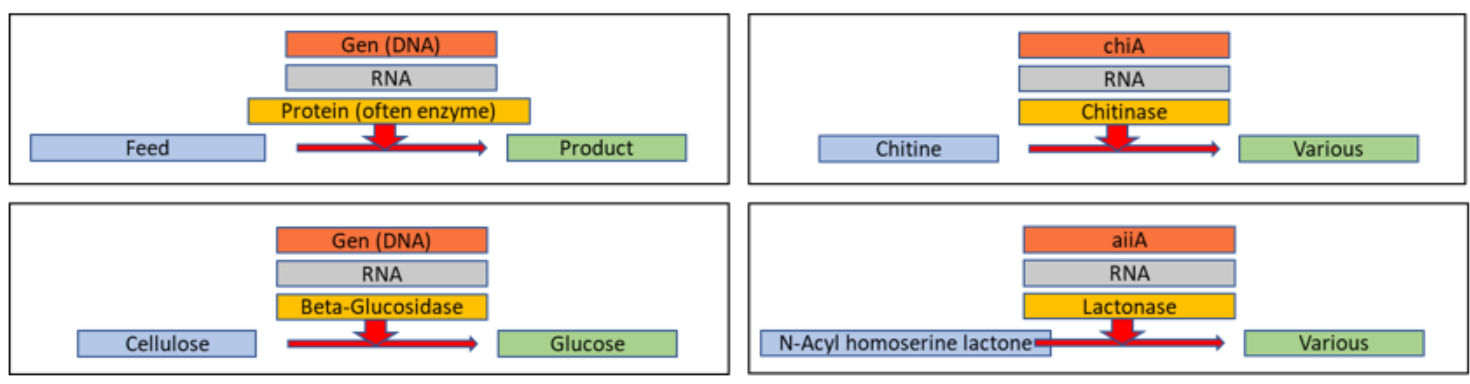

Figure 2. Schematic representation for one general and three actual bacterial processes in which a feed (blue), the resulting product (green), the enzyme responsible (orange), the unique RNA (grey) and DNA (red) involved are given. The rate of conversion of the feed can be characterized by any of the five methods but interpretation becomes more challenging from bottom to top. Interpretation may be difficult when substances similar to feed or product are present.

\section{Recirculation}

\section{Potential.}

Our argument to promote worldwide recirculation of drainage in growing media based systems is that this solution is both, technically possible and economically feasible. The advantages are huge: a 50\% decrease in water use compared to free draining greenhouse cultivation and a $60 \%$ decrease in nutrient use. Furthermore emission of water borne chemicals is zero and the production is area efficient (Gruda, 2020).

\section{Biodiversity and rewilding.}

An overarching advantage of using growing media in which both recirculation and the use of more circular fertilisers play a significant role is the influence on biodiversity and rewilding. As we have seen, both recirculation and circular fertilisers reduce the diffuse emission of nutrients into the environment which benefits biodiversity. Furthermore, the very high yield levels or related water use efficiency and nutrient use efficiency also result in growing media systems with drainage water recirculation being area efficient. The area dedicated to growing media based production worldwide is perhaps 100,000 ha or $1000 \mathrm{~km}^{2}$, the total production is about 30 Mton fresh product or 1.5 Mton dry weight. Energy wise this is $12 * 1015 \mathrm{~J}$ (counting $8 \mathrm{MJ} \mathrm{kg}^{-1}$ dry matter). The annual energy intake of the world population is about $18^{*} 1018 \mathrm{~J}$, counting an intake of $7 \mathrm{MJ} \mathrm{d}^{-1},(\mathrm{FAO}, 2009)$. Thus, the relevance of growing media production is modest indeed with slightly less than $0.1 \%$ of the total required production. However, the world's area in cultivation is $20 \mathrm{Mkm}^{2}$, of which growing media 
based production is $0.005 \%$. Thus 1 unit area of growing media based production is on average 20 times more productive than the average unit of cultivated land (Zhou et al., 2021). This indicates that conversion of arable cropping to substrate based cultivation could free significant areas for rewilding (Attenborough, 2020), which is another way to restore biodiversity. It is however fair to point out another $40 \mathrm{M} \mathrm{km}^{2}$ is dedicated to livestock production, which is perhaps an even easier target for rewilding (FAO, 2020).

\section{Knowledge gaps.}

Growing media systems with drainage water recirculation are possibly not the best available area efficient alternative for an emission free production system for global production of relevant quantities of healthy food. Better alternatives possibly are free ranging forestry systems from which green mass is harvested for insect or microbial conversion into food (Van Hofwegen et al., 2009; Huis et al., 2013). In such systems, only parts of the plants are harvested i.e. the plants remain healthy and functional in their natural habitat. Although in theory such systems outperform growing media systems with drainage water recirculation, there is very little knowledge of actual systems. For the decades to come growing media systems with drainage water recirculation seem a relatively efficient way to free considerable areas for, hopefully, rewilding.

Growing media systems result in the covering and dehydration of a once living soil. What value do we attach to this loss of living soil? This question is almost philosophical but can also be quantified by measuring the loss of soil life (Erisman et al., 2016). To put this discussion in perspective; this same argument applies to the building of cities, especially cities in the world's deltas as such deltas are among the most productive areas. A solution of sorts is to promote establishing greenhouses with growing media systems with drainage water recirculation in areas with low level of life and natural productivity (deserts and cities).

A more pressing and actual barrier preventing the adaptation of growing media systems with drainage water recirculation is the need to frequently adapt the level of single elements (Beerling et al., 2014; Massa et al., 2020). This is a huge obstacle for growers who are not trained in the management of complex mixes of chemicals. The process requires calculations and weighing and even a small mistake can damage a crop beyond hope of recovery. There has been little progress in decreasing this risk for growers with a poor understanding of fertilisers, let alone recirculation. Automation and training still leave room for ample improvements. Automation includes sensor development and decision making software.

\section{Circular fertilisers}

\section{Potential.}

The potential of using circular fertilisers is to replace all the non-circular fertilisers which go into the crop and still end up as diffuse emission via plant waste, animal waste and human waste. This is a huge system transition which redefines agriculture and, as discussed, counters the loss of biodiversity.

\section{Knowledge gaps.}

The replacement of non-circular fertilizers with circular fertilizers for the total world food production is in the end perhaps not possible because of inevitable losses of matter from grower to consumer and vice versa (De Boer and van Ittersum, 2018). For Dutch horticulture however, it is quite possible to get access to sufficient amounts of circular nutrients.

At present there is no fertiliser recommendation system for organic fertilisers in horticulture. The difficulty of such a system is that levels of 16 elements will be monitored and independently adjusted. As most organic fertilisers are compound fertilisers, i.e. contain several elements, this greatly complicates corrections which are inherent to recirculation schedules. For corrections a market for either noncircular single fertilisers or circular single fertilizers will remain. Single fertilisers are a salt of one cation species and one anion species i.e. the simplest combination of one or two nutrients.

When using organic waste streams as feed to generate plant nutrition containing all 
elements, much attention focuses on the nitrogen content of the feed. This is no accident as in nature, nitrogen is often the element limiting plant growth. Nitrogen is not only lost from the natural nutrient cycle as drainage, but also as the gasses ammonia, nitrogen or, more rarely, NOx. For this reason, natural cycles for nitrogen ultimately depend on the production of ammonia and nitrate from nitrogen in the air by lightning and by various bacteria, notably the Rhizobia symbiosis with leguminous plants. Thus, nitrogen in organic waste streams is relatively scarce. Furthermore, nitrogen in organic waste streams is often bound in organic molecules as proteins or DNA/RNA molecules. As the plant can only take them in as ammonium or nitrate, further bacterial conversions are necessary (Grunert et al., 2016b). There are several reasons why the conversion of $\mathrm{N}$-organic is often rate limiting in growing media systems (Grunert, 2017). Firstly the growth rates of growing media grown plants are up to ten times higher than in soil (Stanghellini, 2014). Secondly the volume of growing media is about 30 times smaller than in soil systems. The combination of these two facts implicate that the conversion rate of organic nitrogen should be at least 300 times faster in growing media than in soil, expressed per unit volume of medium. As nitrite oxidising bacteria grow slow and require a pH of about 6.5, it takes days to weeks for the bacteria to increase their activity to the required rates (Blok et al., 2017c). Applying (circular) organic growing media thus requires specific new knowledge on supplying sufficient mineral $\mathrm{N}$ through microbial processes.

\section{Resilience}

\section{Potential.}

The suppression of diseases with microorganisms in the growing medium would complement the progress made with above ground integrated pest management (IPM). Such a development would support an already emerging billion dollar industry and would allow growers to produce without using chemical crop protection agents (Leymonie and Perata, 2013; Lugtenberg, 2015). The impact could hardly be overestimated as the progress made in horticulture in this field is believed to also lead the way for more general agricultural applications.

\section{Knowledge gaps.}

\section{Microbial abundance in growing media.}

It is unclear what the "right" general number of microorganisms is in various growing media because of: a) lack of data on many growing media; b) a lack of knowledge of microbial abundance and activity in time i.e. in many growing media microbial abundance can greatly differ over time during cultivation. Once in cultivation, after dry storage, it may take weeks before the numbers and activities of microorganisms approach equilibrium with the new circumstances of moisture content, nutrients, $\mathrm{pH}$ and temperature. It is often important to have an idea of microbial activity and abundance in growing media for it influences the chances of survival of an added biostimulant or biological control agent.

\section{The application method of biostimulants/biological control agents.}

It is usually not enough to add a biostimulant or biocontrol agent as a drench at one spot or as a solid in a thin layer between propagation medium and cultivation medium. Even though roots have shown they are able to pick up and transport some microorganisms on their surface when growing through a layer of added biostimulant or biocontrol agent (Hassan et al., 2019), it looks as if much research on the proper distribution of biostimulants or biocontrol agents is still to be done.

One-time application versus continuous application.

Many biostimulants and biocontrol agents or their feed are added only once or at a low interval, without any measured indicator to decide when to re-apply. Especially biostimulants/biocontrol agents/feeds which can be fertigated can be applied more 
frequently. It may be more effective to supply regularly in small quantities, preferably via the already existing drip irrigation system. Alternatively, it may also be effective to offer slow releasing formulations and distribute these evenly through the propagation and cultivation media.

\section{Functional groups.}

Functional groups are an appealing idea and the present-day knowledge of useful functional groups is vast, although perhaps not yet complete. What is sometimes lacking are the means to control the natural communities enough to maintain a lasting disease suppression. Such means include a supply of feed, temperature, moisture content, oxygen supply and $\mathrm{pH}$.

\section{Bioassays}

To study the means to control natural communities, biostimulants and biocontrol agents in order to maintain a lasting disease suppression, fast and cost economic bioassays may offer a systematic framework. At present we lack knowledge on dose and method of application, a standard to compare and evaluate effects and duration of effects on microorganisms and on the suppression of diseases. Such bioassays are likely to be very specific for the growing medium used and the crop, even variety, grown on it. Growing media researchers could help develop such bioassays to more systematically improve our understanding of the management of resilience.

\section{Selected methods and their usefulness.}

We now have methods to find number of DNA copies, though this may include dead and inactive DNA. We can also measure RNA copies which are short lived so a good measure of DNA activity which is not the same as the activity of a functional group. We can measure many but not all enzymes as an indicator of potential activity and for some enzymes even actual activity. And sometimes we can measure either the feed or product of a specific reaction as a closer indicator of actual activity in a growing medium (Figure 2). When using one or more specific methods it is helpful to discuss the limits of the method. At present qPCR methods are often used to measure the number of specific copies present. qPCR needs to be calibrated with a marker because of the errors, which may be the result of differences in DNA/RNA extraction efficiency when extracting from different growing substrates. Therefore, a discussion on the appropriateness and robustness of the methods used is much needed in article discussions.

\section{CONCLUSIONS}

The use of growing media in combination with recirculation of drainage water increases production per unit area, increases water use efficiency by $50 \%$, nutrient use efficiency by $60 \%$ and eliminates the emission of water borne chemical agents. Worldwide this may be a core mission for growing media producers and national authorities. A secondary effect of increasing importance in the public discussion is the possibility to use growing media based systems to free a considerable area for rewilding.

Local organic wastes can be used in the fertilisation of growing media systems. The technical knowledge in horticulture requires valorisation of organic mass into solid slow release and in liquid fertilisers. Open field agriculture and outdoor irrigated agriculture could greatly benefit from such developments. Developing and applying such high-quality circular fertilisers contributes to halting a world-wide loss in biodiversity. It is up to the horticultural industry and research to convince consumers and authorities to allow horticulture to lead in this aspect.

Growing media with inherent disease suppression still require massive amounts of research and a more equal cooperation between university researchers and industry researchers. The focus however is already shifting toward standardised quality tests, field monitoring and advice on maintenance applications of biostimulants and specific microbial feed.

All of the above asks for involvement of growing media producers in the societal debate 
on the merits of growing media systems as well as a much higher transfer of knowledge of growing media research to users to be able to deal with recirculation, organic fertilisers and resilient growing media.

\section{Literature cited}

Alabouvette, C., and Steinberg, C. (2006). The soil as a reservoir for antagonists to plant diseases. In An Ecological and Societal Approach to Biological Control, J. Eilenberg, and H.M.T. Hokkanen, eds., p.123-144.

Antoniou, A., Tsolakidou, M.-D., Stringlis, I.A., and Pantelides, I.S. (2017). Rhizosphere microbiome recruited from a suppressive compost improves plant fitness and increases protection against vascular wilt pathogens of tomato. Front Plant Sci 8, 2022 https://doi.org/10.3389/fpls.2017.02022. PubMed

Attenborough, D. (2020). A Life on Our Planet: My Witness Statement and a Vision for the Future (Ebury Publishing).

Barrett, G.E., Alexander, P.D., Robinson, J.S., and Bragg, N.C. (2016). Achieving environmentally sustainable growing media for soilless plant cultivation systems - a review. Sci. Hortic. (Amsterdam) 212, 220-234 https://doi.org/10.1016/j.scienta.2016.09.030.

Beerling, E., Blok, C., Van der Maas, A., and Van Os, E.A. (2014). Closing the water and nutrient cycles in soilless cultivation systems. Acta Hortic. 1034, 49-55 https://doi.org/10.17660/ActaHortic.2014.1034.4.

Beerling, E., Blok, C., Balendonck, J., Leyh, R., van Os, E.A., and Voogt, W. (2017). Closing water and nutrient cycles in greenhouse horticulture (Poster Fertinowa).

Blok, C., and Verhagen, H. (2009). Trends in rooting media in dutch horticulture during the period 2001-2005. The New Growing Media Project. Acta Hortic. 819, 47-58 https://doi.org/10.17660/ActaHortic.2009.819.4.

Blok, C., Jackson, B.E., Guo, X., de Visser, P.H.B., and Marcelis, L.F.M. (2017a). Maximum plant uptakes for water, nutrients, and oxygen are not always met by irrigation rate and distribution in water-based cultivation systems. Front Plant Sci 8, 562 https://doi.org/10.3389/fpls.2017.00562. PubMed

Blok, C., Streminska, M., and Vermeulen, T. (2017b). Ammonium conversion in liquid organic fertilisers. Acta Hortic. 1168, 11-18 https://doi.org/10.17660/ActaHortic.2017.1168.2.

Blok, C., Streminska, M., Vermeulen, T., and Klein, P. (2017c). Organic fertilisers and nitrogen availability. Acta Hortic. 1168, 1-10 https://doi.org/10.17660/ActaHortic.2017.1168.1.

Blok, C., Eveleens, B., and van Winkel, A. (2021). Growing media for food and quality of life in the period 20202050. Acta Hortic. 1303, 341-356 https://doi.org/10.17660/ActaHortic.2021.1305.46.

Carlile, W., and Waller, P. (2013). Peat, politics and pressure groups. Chron. Hortic. 53, 10-17.

Cretoiu, M.S., Korthals, G.W., Visser, J.H.M., and van Elsas, J.D. (2013). Chitin amendment increases soil suppressiveness toward plant pathogens and modulates the actinobacterial and oxalobacteraceal communities in an experimental agricultural field. Appl. Environ. Microbiol. 79 (17), 5291-5301 https://doi.org/10.1128/AEM.01361-13. PubMed

De Boer, I.J.M., and van Ittersum, M.K. (2018). Circularity in agricultural production. Scientific basis for the Mansholt Lecture 2018. "Towards a circular agriculture and food system in Europe". Animal Production Systems, 2 Plant Production Systems (Wageningen, the Netherlands).

De Gelder, A., Warmenhoven, M., Kromdijk, W., Meinen, E., De Zwart, F., Stolker, H., and Grootscholten, M. (2019). Gelimiteerd $\mathrm{CO}_{2}$ en het nieuwe telen. Tomaat (Wageningen, The Netherlands: Wageningen University \& Research, Greenhouse Horticulture).

De Tender, C., Mesuere, B., Van der Jeugt, F., Haegeman, A., Ruttink, T., Vandecasteele, B., Dawyndt, P., Debode, J., and Kuramae, E.E. (2019). Peat substrate amended with chitin modulates the N-cycle, siderophore and chitinase responses in the lettuce rhizobiome. Sci. Rep. 9 (1), 9890 https://doi.org/10.1038/s41598-019-46106-x. PubMed

Debode, J., De Tender, C., Cremelie, P., Lee, A.S., Kyndt, T., Muylle, H., De Swaef, T., and Vandecasteele, B. (2018). Trichoderma-inoculated miscanthus straw can replace peat in strawberry cultivation, with beneficial effects on disease control. Front Plant Sci 9, 213 https://doi.org/10.3389/fpls.2018.00213. PubMed

Dogliotti, S., Giller, K.E., and Van Ittersum, M.K. (2014). Achieving global food security whilst reconciling demands on the environment: Report of the First International Conference on Global Food Security. 6, 299-302.

Du Jardin, P. (2015). Plant biostimulants: definition, concept, main categories and regulation. Sci. Hortic. (Amsterdam) 196, 3-14 https://doi.org/10.1016/j.scienta.2015.09.021.

EN-13432 (2017). Compostability. 
EN-17033 (2018). Plastics - Biodegradable Mulch Films for Use in Agriculture and Horticulture - Requirements and Test Methods.

Erisman, J.W., van Eekeren, N., de Wit, J., Koopmans, C., Cuijpers, W., Oerlemans, N., and Koks, B.J. (2016). Agriculture and biodiversity: a better balance benefits both. AIMS Agriculture and Food 1, 157-174 https://doi.org/10.3934/agrfood.2016.2.157.

Eveleens, B., and Blok, C. (2020). Biodegradable twines in horticulture. Greenhouse test tomato - contact with dealers and composters (Wageningen, The Netherlands: Wageningen University \& Research, Greenhouse Horticulture).

FAO. (2009). How to feed the world in 2050. In High Level Expert Forum, FAO, ed. (Rome, Italy: FAO).

FAO. (2017). The future of food and agriculture. Trends and challenges. In Trends and Challenges, FAO, ed. (Rome. Italy: FAO).

FAO (2020). FAO statistical yearbook 2020. World food and agriculture. F.A.O. Statistical Yearbooks, ed. (Rome, Italy: FAO).

Foley, J.A., Defries, R., Asner, G.P., Barford, C., Bonan, G., Carpenter, S.R., Chapin, F.S., Coe, M.T., Daily, G.C., Gibbs, H.K., et al. (2005). Global consequences of land use. Science 309 (5734), 570-574 https://doi.org/10.1126/science.1111772. PubMed

Fryda, L., Visser, R., and Schmidt, J. (2019). Biochar replaces peat in horticulture: environmental impact assessment of combined biochar \& bioenergy production. Detritus 5, 132-149.

Gerrewey, T.V., Vandecruys, M., Ameloot, N., Perneel, M., Labeke, M.-C.V., Boon, N., and Geelen, D. (2020). Microbeplant growing media interactions modulate the effectiveness of bacterial amendments on lettuce performance inside a plant factory with artificial lighting. Agronomy (Basel) 10 (10), 10 https://doi.org/10.3390/agronomy10101456.

Glodowska, M. 2014. Biochar as a potential inoculant carrier for plant-beneficial bacteria. Master thesis (Montreal, Canada: Faculty of Agriculture and Environmental Sciences, Department of Plant Science, Macdonald Campus of McGill University).

Gonani, Z., Riahi, H., and Sharifi, K. (2011). Impact of using leached spent mushroom compost as a partial growing media for horticultural plants. J. Plant Nutr. 34 (3), 337-344 https://doi.org/10.1080/01904167.2011.536876.

Gruda, N.S. (2020). Increasing sustainability of growing media constituents and stand-alone substrates in soilless culture systems. Agronomy (Basel) 9 (6), 298 https://doi.org/10.3390/agronomy9060298.

Grunert, O. (2017). Microbially managed organic growing media for greenhouse horticulture. PhD thesis (Ghent, Belgium: Ghent University).

Grunert, O., Hernandez-Sanabria, E., Vilchez-Vargas, R., Jauregui, R., Pieper, D.H., Perneel, M., Van Labeke, M.-C., Reheul, D., and Boon, N. (2016a). Mineral and organic growing media have distinct community structure, stability and functionality in soilless culture systems. Sci. Rep. 6 (1), 18837 https://doi.org/10.1038/srep18837. PubMed

Grunert, O., Reheul, D., Van Labeke, M.C., Perneel, M., Hernandez-Sanabria, E., Vlaeminck, S.E., and Boon, N. (2016b). Growing media constituents determine the microbial nitrogen conversions in organic growing media for horticulture. Microb. Biotechnol. 9 (3), 389-399 https://doi.org/10.1111/1751-7915.12354. PubMed

Grunert, O., Robles-Aguilar, A.A., Hernandez-Sanabria, E., Schrey, S.D., Reheul, D., Van Labeke, M.C., Vlaeminck, S.E., Vandekerckhove, T.G.L., Mysara, M., Monsieurs, P., et al. (2019). Tomato plants rather than fertilizers drive microbial community structure in horticultural growing media. Sci. Rep. 9 (1), 9561 https://doi.org/10.1038/s41598-01945290-0. PubMed

Hassan, M.K., McInroy, J.A., and Kloepper, J.W. (2019). The interactions of rhizodeposits with plant growthpromoting rhizobacteria in the rhizosphere. Rev. Agric. (Piracicaba) 9, 142.

HortiDaily. (2020). Reversed osmosis in combination with Artificial Intelligence. HortiDaily 2020 (10), 14.

Huis, A.v., Itterbeeck, J.v., Klunder, H., Mertens, E., Halloran, A., Muir, G., and Vantomme, P. (2013). Edible insects: future prospects for food and feed security (Rome Food and Agriculture Organization of the United Nations).

Hultberg, M., Bergstrand, K.-J., Khalil, S., and Alsanius, B. (2008). Production of biosurfactants and antibiotics by fluorescent pseudomonads isolated from a closed hydroponic system equipped with a slow filter. Antonie van Leeuwenhoek 93 (4), 373-380 https://doi.org/10.1007/s10482-007-9214-y. PubMed

IFA (2014). Fertilizerfacts: Ammonia production: moving towards maximum efficiency and lower GHG emissions. Fertilizerfacts July 2014.

IPBES. (2019). Summary for policymakers of the global assessment report on biodiversity and ecosystem services of the Intergovernmental Science-Policy Platform on Biodiversity and Ecosystem Services. S. Díaz, J. Settele, E.S. 
Brondízio E.S., H.T. Ngo, M. Guèze, J. Agard, A. Arneth, P. Balvanera, K.A. Brauman, S.H.M. Butchart, K.M.A. Chan, L.A Garibaldi, K. Ichii, J. Liu, S.M. Subramanian, G.F. Midgley, P. Miloslavich, Z. Molnár, D. Obura, A. Pfaff, S. Polasky, A. Purvis, J. Razzaque, B. Reyers, R. Roy Chowdhury, Y. J. Shin, I.J. Visseren-Hamakers, K.J. Willis, and C.N. Zayas, eds. (Bonn, Germany: IPBES secretariat), pp.56. https://doi.org/10.5281/zenodo.3553579

Joos, L., Beirinckx, S., Haegeman, A., Debode, J., Vandecasteele, B., Baeyen, S., Goormachtig, S., Clement, L., and De Tender, C. (2020). Daring to be differential: metabarcoding analysis of soil and plant-related microbial communities using amplicon sequence variants and operational taxonomical units. BMC Genomics 21 (1), 733 https://doi.org/10.1186/s12864-020-07126-4. PubMed

Khalil, S., Hultberg, M., and Alsanius, B.W. (2011). Interactions between growing media and biocontrol agents in closed hydroponic systems. Acta Hortic. 891, 51-57 https://doi.org/10.17660/ActaHortic.2011.891.4.

Leymonie, J.P., and Perata, P. (2013). Biostimulants in agriculture: a new field of research for plant and crop scientists, an opportunity for sustainable agriculture. Biostimulants: what's behind the name? Chron. Hortic. 53, 37-39.

LNV (2019). Plan of action. The Dutch government's plan to support the transition to circular agriculture (The Hague, The Netherlands: Ministry of Agriculture, Nature and Food Quality).

Lugtenberg, B. (2015). Principles of Plant-Microbe Interactions: Microbes for Sustainable Agriculture (Cham: Springer International Publishing).

Ma, H.-K., Pineda, A., van der Wurff, A.W.G., Raaijmakers, C., and Bezemer, T.M. (2017). Plant-soil feedback effects on growth, defense and susceptibility to a soil-borne disease in a cut flower crop: species and functional group effects. Front Plant Sci 8, 2127 https://doi.org/10.3389/fpls.2017.02127. PubMed

Massa, D., Magán, J.J., Montesano, F.F., and Tzortzakis, N. (2020). Minimizing water and nutrient losses from soilless cropping in southern Europe. Agric. Water Manage. 241, 106395 https://doi.org/10.1016/j.agwat.2020.106395.

Muter, O., Grantina-Levina, L., and Makarenkova, G. (2017). Effect of biochar and Trichoderma application on fungal diversity and growth of Zea mays in a sandy loam soil. Environ. Exp. Biol. 15, 289-296.

OECD. (2021). Making Better Policies. In OECD Report.

OECD-FAO (2014). OECD Compendium of Agri-environmental Indicators.

OECD-FAO. (2021). Agricultural Outlook 2020-2029. In OECD-FAO Agricultural Outlook (OECD-FAO).

Postma, J. (2004). Suppressiveness of root pathogens in closed cultivation systems. Acta Hortic. 644, 503-510 https://doi.org/10.17660/ActaHortic.2004.644.67.

Postma, J., and Schilder, M.T. (2015). Enhancement of soil suppressiveness against Rhizoctonia solani in sugar beet by organic amendments. Appl. Soil Ecol. 94, 72-79 https://doi.org/10.1016/j.apsoil.2015.05.002.

Raviv, M. (2009). Recent advances in soil-borne disease control using suppressive media. Acta Hortic. 819, 125134 https://doi.org/10.17660/ActaHortic.2009.819.11.

Raworth, K. (2017). Doughnut economics: seven ways to think like a $21^{\text {st }}$ century economist (White River Junction, Vermont: Chelsea Green Publishing).

Reinhardt, D.H., and Sharma, A.K. (2019). Methods in Rhizosphere Biology Research (Singapore: Springer).

Schmilewski, G. (2009). Growing medium constituents used in the EU. Acta Hortic. 819, 33-46 https://doi.org/10.17660/ActaHortic.2009.819.3.

Silber, A., Bruner, M., Kenig, E., Reshef, G., Zohar, H., Posalski, I., Yehezkel, H., Shmuel, D., Cohen, S., Dinar, M., et al. (2005). High fertigation frequency and phosphorus level: effects on summer-grown bell pepper growth and blossom-end rot incidence. Plant Soil 270 (1), 135-146 https://doi.org/10.1007/s11104-004-1311-3.

Sonneveld, C., and Voogt, W. (2009). Plant Nutrition of Greenhouse Crops (Springer).

Stanghellini, C. (2014). Horticultural production in greenhouses: efficient use of water. Acta Hortic. 1034, 25-32 https://doi.org/10.17660/ActaHortic.2014.1034.1.

Stanghellini, C., van 't Ooster, B., and Heuvelink, E. (2019). Greenhouse Horticulture. Technology for optimal crop production (Wageningen, The Netherlands: Wageningen Academic Publishers).

Termorshuizen, A.J., van Rijn, E., van der Gaag, D.J., Alabouvette, C., Chen, Y., Lagerlöf, J., Malandrakis, A.A., Paplomatas, E.J., Rämert, B., Ryckeboer, J., et al. (2006). Suppressiveness of 18 composts against 7 pathosystems: variability in pathogen response. Soil Biol. Biochem. 38 (8), 2461-2477 https://doi.org/10.1016/j.soilbio.2006.03.002.

Tian, X., Zhao, X., Mao, Z., and Xie, B. (2019). Dynamics of Soil Nematode Communities Revealed Significant Variation in Greenhouse with Different Continuous Cropping Years. bioRxiv, 593541. 
UN (2021). World Population Prospects 2019 (New York, USA: Department of Economic and Social Affairs, United Nations).

UNESCO. (2019). UNESCO World Water Assessment Programme.

Van der Velden, N.J.A., and Smit, P.X. (2019). $\mathrm{CO}_{2}$-behoefte glastuinbouw 2030 (Wageningen, The Netherlands: Wageningen Economic Research).

Van der Velden, N., and Smit, P. (2020). Energiemonitor van de Nederlandse glastuinbouw 2018, LEI, ed.

Van der Velden, N.J.A., Smit, P.X., and Buurma, J.S. (2018). Prognoses $\mathrm{CO}_{2}$-emissie glastuinbouw 2030 (Wageningen, The Netherlands: Wageningen Economic Research).

Van Hofwegen, G., Kuyper, T.W., Hoffland, E., Van den Broek, J.A., and Becx, G.A. (2009). Opening the Black Box: Deciphering Carbon and Nutrient Flows in Terra Preta. In Amazonian Dark Earths: Wim Sombroek's Vision (Springer Netherlands), p.393-409.

Van Os, E.A., Eling, A., and Voogt, W. (2009). The water balance in Ethiopian greenhouses. A case study for two rose farms. Wageningen University \& Research, Greenhouse Horticulture (Wageningen, The Netherlands).

Van Os, E.A., Beerling, E.A.M., Blok, C., Janse, J., Leyh, R., van Ruijven, J.P.M., van der Staaij, M., and Kaarsemaker, R. (2019). Zero discharge of nutrients and pesticides to the environment in hydroponic production. Acta Hortic. 1266, 443-450 https://doi.org/10.17660/ActaHortic.2019.1266.61.

Van Staalduinen, J., and Verhagen, H. (2020). Organic fertilisers in substrates can produce surprising results. In Greenhouses 4, 52-53.

Vandecasteele, B., Muylle, H., De Windt, I., Van Acker, J., Ameloot, N., Moreaux, K., Coucke, P., and Debode, J. (2018). Plant fibers for renewable growing media: potential of defibration, acidification or inoculation with biocontrol fungi to reduce the $\mathrm{N}$ drawdown and plant pathogens. J. Clean. Prod. 203, 1143-1154 https://doi.org/10.1016/j.jclepro.2018.08.167.

Vandecasteele, B., Blindeman, L., Amery, F., Pieters, C., Ommeslag, S., Van Loo, K., De Tender, C., and Debode, J. (2020). Grow - Store - Steam - Re-peat: reuse of spent growing media for circular cultivation of Chrysanthemum. J. Clean. Prod. 276, 124128 https://doi.org/10.1016/j.jclepro.2020.124128.

Vandecasteele, B., Pot, S., Maenhout, K., Delcour, I., Vancampenhout, K., and Debode, J. (2021). Acidification of composts versus woody management residues: optimizing biological and chemical characteristics for a better fit in growing media. J. Environ. Manage. 277, 111444 https://doi.org/10.1016/j.jenvman.2020.111444. PubMed

Verhagen, J.B.G.M. (2013). Oxygen diffusion in relation to physical characteristics of growing media. Acta Hortic. 1013, 313-318 https://doi.org/10.17660/ActaHortic.2013.1013.38.

Verkerke, W., and Boedijn, A. (2020). Transitie naar een Circulaire Glastuinbouw.

Vestberg, M., Kukkonen, S., Rantala, S., Prochazka, P., Tuohimetsä, S., Setälä, H., Romantschuk, M., Kurola, J., Yu, D., and Parikka, P. (2011). Suppressiveness of Finnish Commercial Compost against Soil Borne Disease. Acta Hortic. 891, 59-66 https://doi.org/10.17660/ActaHortic.2011.891.5.

Viaene, J., Nelissen, V., Reubens, B., Willekens, K., Driehuis, F., De Neve, S., and Vandecasteele, B. (2017). Improving the product stability and fertilizer value of cattle slurry solid fraction through co-composting or co-ensiling. Waste Manag. 61, 494-505 https://doi.org/10.1016/j.wasman.2016.12.037. PubMed

WallisDeVries, M.F., and van Swaay, C.A.M. (2017). A nitrogen index to track changes in butterfly species assemblages under nitrogen deposition. Biological Conservation 212, Part B, 448-453.

Ward. (2017). https://ec.europa.eu/info/sites/info/files/conferences/food2030_2017/3.6.3_sustainable _techno-economic_solutions_agrocycle-shane_ward_0.pdf

Weller, D.M., Raaijmakers, J.M., Gardener, B.B.M., and Thomashow, L.S. (2002). Microbial populations responsible for specific soil suppressiveness to plant pathogens. Annu. Rev. Phytopathol. 40 (1), 309-348 https://doi.org/10.1146/annurev.phyto.40.030402.110010. PubMed

Withers, P.J.A., Sylvester-Bradley, R., Jones, D.L., Healey, J.R., and Talboys, P.J. (2014). Feed the crop not the soil: rethinking phosphorus management in the food chain. Environ. Sci. Technol. 48 (12), 6523-6530 https://doi.org/10.1021/es501670j. PubMed

Wubs, E.R.J., Melchers, P.D., and Bezemer, T.M. (2018). Potential for synergy in soil inoculation for nature restoration by mixing inocula from different successional stages. Plant Soil 433 (1), 147-156 https://doi.org/10.1007/s11104-018-3825-0. PubMed

Xu, G., Levkovitch, I., Soriano, S., Wallach, R., and Silber, A. (2004). Integrated effect of irrigation frequency and phosphorus level on lettuce: $P$ uptake, root growth and yield. Plant Soil 263 (1), 297-309 https://doi.org/10.1023/B:PLSO.0000047743.19391.42. 
Zhou, D., Meinke, H., Wilson, M., Marcelis, L.F.M., and Heuvelink, E. (2021). Towards delivering on the sustainable development goals in greenhouse production systems. Resour. Conserv. Recycling 169, 105379 https://doi.org/10.1016/j.resconrec.2020.105379. 
